and the first essential is to assess inhaler technique and to correct it if necessary. Even with education some patients cannot acquire hand-lung coordination, and an alternative handheld inhalational device may need to be introduced..$^{30}$ Peak expiratory flow and symptom scores (on diary cards) should be monitored at home and used to assess response to correctly administered $\beta$ agonists and oral and inhaled corticosteroids. Many patients may be managed satisfactorily in this way, but those who are poorly controlled with conventional medication but respond to high dose inhaled $\beta$ agonist treatment are considered for nebuliser treatment. Alternative devices for high dose drug administration (Rotahaler, Nebuhaler) are often tried first but failure leads to a trial of home nebulisation. Laboratory assessment indicates the optimal dosages of $\beta$ agonist (which for salbutamol should rarely exceed $5 \mathrm{mg}^{31}$ ), frequency of delivery, and whether addition of ipratropium bromide provides further bronchodilatation. Each patient is then issued with a written statement of drug dosage and frequency and urged to continue monitoring peak expiratory flow and symptom scores. The respiratory technician gives instruction on the use and cleaning of the nebuliser unit. If the patient improves, appears compliant, does not report troublesome side effects (for example, tremor or angina), and keeps the nebuliser clean, we recommend it for long term use. The patient must be supervised by a clinician fully conversant in the problems of home nebuliser treatment, and a full technical and service back up must be available with regular servicing of the equipment.

Some patients who are normally well controlled with conventional inhaler treatment may have recurrent acute attacks of asthma unresponsive to their usual medication. High dose inhaled bronchodilators may abort an attack. Doctors who recommend home nebulisers or other methods for high dose bronchodilator administration in these circumstances must ensure that patients understand the use of such treatment and will obtain immediate expert help if the expected symptomatic and objective relief (as indicated by improvement in peak expiratory flow) does not occur. Tattersfield has suggested that each nebuliser should carry a warning stating that it is dangerous to exceed the stated dose and that failure to respond indicates that further medical care is necessary..$^{32}$ Immediate planned access to emergency help is essential.

Some 17000 nebuliser units were sold in Britain in 1983. Many would not have been necessary if patients had been adequately assessed, if appropriate treatment had been given with inhaled bronchodilators and corticosteroids, and if alternative inhalational devices had been tried where conventional inhalers failed. The unsupervised acquisition and use of home nebulisers is a reflection of inadequate assessment and management of asthma by doctors. This should not obscure the fact that a few patients with chronic airflow limitation may gain considerable benefit from regular or occasional administration of high doses of inhaled bronchodilator.

G M COCHRANE Consultant physician J G PRIOR Senior registrar P J REES

Department of Thoracic Medicine, Guy's Hospital Medical School, London SE1 9RT

1 Hiller EJ, Milner AD, Lenney W. Nebulised sodium cromoglycate in young asthmatic children. Arch Dis Child 1977;52:875-6.
2 Brogden RN. Inhaled steroids: studies in adult and childhood asthma. In: TJH Clark, ed. Steroids in asthma. Auckland: Adis Press, 1983:149.

3 Hirsch SR, Kory RC. An evaluation of the effect of nebulised N-acetylcysteine on sputum consistency. Fournal of Allergy 1967;39:256-73.

4 Prior JG, Anderson JB, Wardlaw A, Sinclair A, Webb JB. Nebulised lignocaine as anaesthesia for fibreoptic bronchoscopy. Thorax 1984;39:705.

5 Hodson ME, Penketh ARL, Batten JC. Aerosol carbenicillin and gentamicin treatment of Pseudomonas aeruginosa infection in patieuts with cystic fibrosis. Lancet 1981;ii:1137-9.

6 Newman SP, Pavia D, Moren F, Sheahan F, Clarke SW. Deposition of pressurized aerosols in the human respiratory tract. Thorax 1981;36:52-5.

7 Spiro S, Singh CA, Tolfree SEJ, Partridge MR, Short MD. Direct labelling of iprotropium bromide aerosol and its deposition pattern in normal subjects and patients with chronic bronchitis. Thorax 1984;39:423-5.

8 Lewis RA, Flemming JS, Balachandrau, Tattersfield AE. Particle size distribution and deposition from a jet nebuliser: influence of humidity and temperature. Clin Sci 1982;65(suppl):5P

9 Tattersfield AE, NcNichol MW. Salbutamol and isoprenaline. A double blind trial to compare bronchodilator and cardiovascular activity. $N$ Engl F Med 1969;281:1323-6.

10 Walters EH, Cockroft A, Griffiths T, Rochiccioli K, Davies BH. Optimal doses of salbutamol respirator solution: comparison of three doses with plasma levels. Thorax 1981;36:625-8.

11 Godfrey S. Worldwide experience of albuterol (salbutamol). Ann Allergy 1981;47:423-6.

12 Connellan SJ, Wilson RSE. The use of domiciliary nebulised salbutamol in the treatment of severe emphysema. Br J Clin Pract 1979;33:135-6.

13 Boe J. Domiciliary nebulised beta agonists. Eur f Respir Dis 1984;65(suppl):193-203.

14 Prior JG, Cochrane GM. Assessment of optimum dose of inhaled terbutaline in patients with chronic asthma; the use of simple cumulative dose-response curves. Br J Dis Chest 1982;76: 266-8.

15 Prior JG, Nowell RV, Cochrane GM. High dose inhaled terbutaline in the management of chronic severe asthma; comparison of wet nebulisation and tube-spacer delivery. Thorax 1982;37:300-3. 6 Corris PA, Neville, E, Nariman S, Gibson GJ. Dose-response study of inhaled salbutamol powder in chronic airflow obstruction. Thorax 1983;38:292-6.

17 McGivern DV, Ward M, Revill S, Sechiari A, McFarlane J, Davies D. Home nebulisers in severe chronic asthma. Br $\mathcal{J}$ Dis Chest 1984;78:376-82.

18 Gomm S, Keaney NP, Hunt LP, Allen SC, Stretton TB. Dose-response comparison of ipratropium bromide from a metered dose inhaler and by jet nebulisation. Thorax 1983;38:297.

19 Lawford P, Jones BJM, Milledge JS. Comparison of intravenous and nebulised salbutamol in the initial treatment of severe asthma. BrMed $\mathcal{F} 1978 ; 1: 84$.

20 Anderson PB, Goude A, Peake MD. Comparison of salbutamol given by intermittent positivepressure breathing packed aerosol in chronic asthma. Thorax 1982;37:612-6.

21 O'Reilly JF, Buchanan DR, Sudlow MF. Pressurised aerosol with conical spacer is an effective 'Reilly JF, Buchanan DR, Sudlow MF. Pressurised aerosol with conical s

22 Morgan MDL, Singh BV, Frame MH, Williams SJ. Terbutaline aerosol given through pear spacer in acute severe asthma. Br Med f 1982;285:849-50.

23 Grant IWB. Asthma in New Zealand. Br Med f 1983;286:374-7

24 Anonymous. The nebuliser epidemic [Editorial]. Lancet 1984;ii:789-90.

25 Prior JG, Cochrane GM, Raper SM. Ali C, Volans GN. Self poisoning with oral salbutamol. $\mathrm{Br}$ Med J 1981;282:1932.

26 O'Brien IAD, Fitzgerald-Fraser J, Lewin IG, Corrall RJM. Hypokalaemia due to salbutamol overdosage. Br Med f 1981;282:1515.

7 Neville E, Corris PA, Vivian J, Nariman S, Gibson GJ. Nebulised salbutamol and angina. Br Med f 1982;285:796-7.

28 Stainforth JN, Tattersfield AE. Airway responsiveness to high dose nebulised salbutamol in chronic asthma. Clin Sci 1983;64:13.

29 Saunders KB. Misuse of inhaled bronchodilator agents. Br Med 7 1965; i:1037-8.

30 Patterson IC, Crompton GK. Use of pressurised inhalers by asthmatic patients. Br Med 7 1976;i:76.

31 Ruffin RE, Obwiniski G, Newhouse MT. Aerosol salbutamol administration by IPPB: lowest effective dose. Thorax 1978;33:689-93.

32 Tattersfield AE. Nebulisers in domiciliary practice. Lancet 1985; i:48-9.

\section{Two cheers for the computer?}

"It is extraordinary to consider that the general form of a scientific paper has changed less, in nearly 300 years, than any other class of literature, except the bedroom farce."'

The past year is likely to be remembered by medical journals as the one when computers came into their own. For some years large editorial offices have used computers for listing referees and keeping track of manuscripts, while libraries have had data bases of references and abstracts available on line. This year has seen two new developments: the transmission on line of complete articles from general medical journals and the launch of an electronic journal, Clinical Notes On-line.

The journals concerned in the first of these developments are the Annals of Internal Medicine, BMF, Lancet, and New England Fournal of Medicine. In the USA all the scientific articles that have appeared for the past three years can now be obtained on a videodisplay unit at home or in the office through the Bibliographic Retrieval Services network, and under the name "Colleague" the service will be extended to Europe later this year. There are plans to include the main 
American and British specialty journals in the system, so before long the system will be fairly comprehensive. At present illustrations and complex tables cannot be transmitted in the computer, but this is only a minor drawback, and almost certainly this problem will be solved before long.

Clinical Notes On-line is published both electronically and conventionally as a printed monthly journal. ${ }^{2}$ It aims, its editor states in the first issue, at harvescing "the vast body of interesting, unique, and unusual cases that all doctors encounter from time to time." Using a standard format, authors can submit brief contributions by post, or "upload" them by telephone from their own microcomputers to the journal office in Lancaster. Electronic handling may also be used for peer review and correspondence with the author and should ensure that publication is prompt: provided the editor does not have to refer back to the author, contributions will be included in the $C N O L$ database within an average of three weeks of receipt.

So far, then, so good. Surely anybody who has visualised speedy and unfettered publication of material that might otherwise not be printed must welcome such a development? Could it not also be extended to cope with the information explosion-rather on the lines originally suggested by the physicist J D Bernal and subsequently developed by the former editor of the Lancet Sir Theodore Fox of having two forms of journal: an archival one and a newspaper $?^{3}$ Yet there is another side to the question, and the unfortunate truth is that cost-benefit analysis of such developments has rarely been in their favour.

Against the advantages of speed, priority, and low cost have to be set the risks of inaccuracy, duplication, and triviality. For over 300 years editors and grant giving bodies have relied on rigorous peer review to eliminate these as far as possible, and, though the system is imperfect, it remains the best insurance against poor quality that we have. Even in those sections of journals where editors allow their contributors rather more licence than usual, manuscripts are submitted to serious internal peer review by an editorial committee. For example, the rejection rate of letters to the editor in the New England Fournal of Medicine and the unreviewed reports of the $B M \mathcal{F}$ is still about $75 \%$, little different from that applying to other types of article. True, $C N O L$ does give some scrutiny to articles, and in the database and printed version these may also be accompanied by comments by the editors and others-yet its policy statement maintains that "communications must be regarded as original, unreviewed observations" and (surely uniquely for a journal) abrogates editorial responsibility when it continues by stating: "the authors accept professional responsibility for their reports" (my italics).

Clearly final judgment on this experiment should be deferred until it has been thoroughly tested. For some topics, such as adverse drug reactions, electronic reporting may be the ideal way of tentatively documenting such informationparticularly if these reports were to be written in a standard format (such as that suggested at the Morges workshop last year ${ }^{4}$ ) and the findings checked beforehand with the drug manufacturers and the national monitoring agency. Nevertheless, past attempts at publishing unrefereed material have usually not been successful. For five years, beginning in 1961, the National Institutes of Health experimented with rapid dissemination of unevaluated preprints. Participants in these "information exchange groups" sent their manuscripts to the NIH, which copied them and forwarded them to other members. By 1966 there were seven such groups with a total membership of $3625 ; 151$ preprints were being sent out every month with an estimated total of 1.5 million copies per year. Potentially further growth might have been large: an estimated 200 groups might have been formed with ultimate costs as high as $\$ 100$ million a year.

Though these preprints had originally been intended to be informal memoranda, as Science pointed out, most of them were publications_ - often being succeeded shortly afterwards by the substantive papers. ${ }^{5}$ This wasteful duplicate publication for some articles together with the poor scientific quality of others led correspondents to the journal to advocate ending the experiment-which was done. A similar debate occurred with a proposal by the American Psychological Association for an early dissemination scheme of unedited and unreviewed manuscripts, one psychologist fearing that the system would become "a vast sewer carrying garbage from one scientist to another," And three years later proposals by Plotkin for a totally electronic journal largely made up of progress reports by scientists to their granting agencies ran into heavy criticism at the annual meeting of the Council of Biology Editors, particularly over the validity of the peer review and the enshrinement of the electronic text as an archive.

To quote Wilfrid Trotter, "the most powerful antigen known to man is a new idea." The idea of electronic publishing is not new, but its realisation is. If it is to succeed I believe it should not ignore the traditions of evaluation built up by conventional publications over several centuries. Clinical Notes On-line is an exciting development that should be welcomed and supported, with two further hopes: firstly, that it will not add worthless fuel to the information explosion; and, secondly, to switch metaphors, that it will not worship the false gods of speed of publication but will stick to the old religion of evaluation by quality, "the discipline essential to the integrity of science."'s

STEPHEN LOCK

Editor, British Medical fourna

1 Ziman J. Public knowledge. Cambridge: Cambridge University Press, 1968

2 Clinical Notes On-line. St Leonards House, St Leonardsgate, Lancaster.

3 Fox T. Crisis in communication. London: Athlone Press, 1965.

4 Anonymous. Improving reports of adverse drug reactions. Br Med f 1984;289:898.

5 Abelson PH. Information exchange groups. Science 1966;154:469.

6 Boffey PM. Psychology: apprehension over a new communication system. Science 1970;167: 1228-30.

7 Pickering G. In: Swales J, ed. Platt versus Pickering. London: Keynes Press, 1985 